\title{
O ATO DE FALA INFELIZ SEGUNDO AUSTIN
}

\author{
THE SPEECH ACT UNHAPPINESS BY AUSTIN
}

Hélcia Macedo de Carvalho Diniz e Silva*

\section{RESUMO}

Esse artigo tem como objetivo geral apresentar a visão pragmática da linguagem a partir do esquema das infelicidades do dizer com base na teoria dos atos de fala proposta por Austin ([1962] 1990), na obra How to do things with words. Algumas vezes os exemplos de atos de fala infelizes são de caráter institucional, outras não, a depender do contexto. Para tanto, estabelece-se a seguinte questão: quais são os fatores que tornam o dizer infelicidades e incidem nos atos de fala malogrados? Parte-se da hipótese de que as infelicidades ocorrem quando há quebras no esquema do proferimento performativo. A metodologia dessa pesquisa é bibliográfica e interpretativista, com caráter qualitativo. Os malogros do dizer como fazer se evidencia nas quebras de alguma parte das etapas do dito. Basicamente, é a situação que define o rigor da ação, ou seja, os sujeitos usam a linguagem para realizar ações. Não obstante, na realização de atos de fala, especificamente, pode acontecer procedimentos infelizes (malogrados ou nulos).

PALAVRAS-CHAVE: Performativos; Atos de fala; Infelicidades do dizer. Ilocucionários.

\begin{abstract}
This article has aim to present the pragmatic vision of language by Auatin ([1962] 1990), he proposes the unhappiness of scheme of to say in the Theory of speech acts, in How to Do Things with Words. Sometimes the exemples of speech acts unhappiness are institucional character, others do not, depending on the context. Therefore, is established the following question: what are the factores that nake the unhapiness say and focus on speech acts foiled. It started from the hypothesis that the unhappiness occur when there are breaks in the performative utterance scheme. The methodology of this research is bibliographic and interpretive, with qualitative. The failures of saying how to do is evident in breaks of some of the steps said. Basically, it is the situation that defines the severity of the action, that is, the subjects use language to perform actions. Nevertheless, in carrying out acts of speech, specifically, it may be unhappy procedures (foiled or null).
\end{abstract}

KEYSWORD: Performatives; Speech acts; Unhappiness of say. Illocutionary.

\footnotetext{
* Doutora em Filosofia. Professora do Centro Universitário de João Pessoa (UNIPÊ) e do Curso de Pedagogia na Modalidade a Distância da Universidade Federal da Paraíba (UFPB). E-mail: helciamacedo@yahoo.com.br.
} 


\section{O ESQUEMA DO ATO DE FALA INFELIZ}

O debate sobre a teoria dos atos de fala enquanto sistema da realização de um ato de fala com sucesso é proposto por Austin, que ressalta o esquema do ato de fala como base do dizer como fazer. A preocupação austiniana está voltada para o dito que faz coisas com palavras, em contextos bem definidos.

O falante faz algo usando a forma "explícita da ação realizada ao se fazer o proferimento 'Estarei lá'. Se alguém diz 'estarei lá', podemos perguntar 'Trata-se de uma promessa?' A resposta pode ser 'Sim"” (AUSTIN, [1962] 1990, p. 67). Se se responder: “Sim, prometo", ou mesmo, "Não prometo, mas pretendo estar lá", essas possibilidades são realizadoras de ações, haja em vista que nada está sendo descrito, nenhum relato está sendo feito ou mesmo não se está apresentando uma realidade. Tais frases são, de fato, atos de fala realizados dentro de determinadas situações que propiciam a realização coisas no mundo.

Isso porque o sistema de atos de fala ilocucionários apresenta o verbo performativo do fazer coisas com palavras e agir dentro de situações bem definidas no contexto. Além deste, Austin propõe os atos locucionários e perlocucionários.

Locucionários: o dizer palavras que mesmo tendo uma sequência lógica e formando frases, sendo estas descontextualizadas, servem para relatar algo ou descrever o mundo que é apresentado.

Ilocucionários: ato de fazer coisas com palavras, geralmente, ditas na primeira pessoa do singular do presente do indicativo da voz ativa. Um dito que compromete aquele que faz o proferimento performativo com força de ação.

Perlocucionários: o dizer que afeta diretamente o outro, seja intencionalmente seja desinteressadamente. Ao proferir tais palavras o sujeito acaba atingindo o seu interlocutor que reage prontamente.

Nesses termos, a categoria primordial do ato de fala é o verbo performativo, dito em contexto enunciativo específico, com pessoas participantes engajadas e circunstâncias que não prescindem do sujeito falante e de seus desejos, crenças e intenções.

Mesmo não tenha sido algo perceptível na tradição, o fazer coisas usando palavras é algo comum na vida das pessoas desde sempre. O fato de elaborar e dizer frases que em muitos casos contém o verbo performativo, ou mesmo, o nome do verbo, faz com que o ser humano realize coisas com o dizer. Quando o verbo é ilocucionário a frase é performativa. 
Conforme explicita Austin ([1962] 1990, p. 68): “ao dizer 'eu prometo que' (se o performativo for feliz, é claro) constitui, sem ambiguidades, uma promessa" [Grifos do filósofo]. Essa é uma ação que pode, também, ser infeliz, como veremos mais adiante.

Dizer "Sim", para realizar o ato de casar é fundamental, desde que o contexto seja o casamento cristão, visto que à ação de casar atrela-se a verbalização de determinadas palavras. Para que se realize o ato de casar sem tropeços, cabe ao ser humano o comprometimento com aquilo que ele diz. Para os noivos é exigido que nunca tenham sido casados antes e que na cerimônia haja testemunhas de ambos os lados.

A linguagem é usada pelo ser humano para fazer coisas, para anunciar uma realidade e para persuadir o outro. Com palavras, realizam-se coisas e o dizer que tal pessoa fez, pode ser feliz ou infeliz. O proferimento performativo obedece às condições de realização e às regras intrínsecas do dizer.

O conceito do termo "Sentença" ilustra o que vem a ser um ato de fala: "O Código de Processo, no art. 162, $\S 1^{\circ}$, denomina sentença o 'ato pelo qual o juiz põe termo ao processo, decidindo ou não o mérito da causa'- assim a sentença é ato que tem como sujeito da manifestação de vontade o juiz" (FILHO, 2001, p. 221).

$\mathrm{Na}$ sentença, o ato de fala realizado ocorre de forma explícita, ou seja, dito na primeira pessoa do singular, no presente do indicativo da voz ativa. Disso, podem resultar diversos acontecimentos. Caso falhe a execução do dizer, podem ocorrer malogros, alguns tropeços com o uso equivocado da linguagem provocando no cotidiano alguns transtornos.

Importante é perceber que o ato de fala é justamente a frase dita, em sua forma explícita ou não. Sendo um proferimento explícito a ocorrência aparece na primeira pessoa do presente do indicativo ativo e tem como centro do ato o verbo ilocucionário. Lembramos que este proferimento é o dizer do sujeito que estabelece relações entre a sua fala e o seu agir.

O dizer funciona como o seu próprio ato. Nos casos em que o verbo não está explicito, então ocorre frases cuja força ilocucionária encontra-se no nome. Há situações em que o verbo está elíptico. "Todo proferimento que seja de fato um performativo deveria ser capaz de ser reduzido, expandido ou analisado de modo tal que se obtivesse uma forma na primeira pessoa do singular do presente do indicativo da voz ativa (gramatical)", explica Austin ([1962] 1990, p. 62). Essa é uma espécie de teste, que serve para identificar, com mais clareza, o dizer como fazer.

Na realidade, nem sempre é possível aplicar esse teste austiniano. Contudo, na grande maioria dos casos de análise de atos de fala esta é uma metodologia cabível para saber qual é 
a classe do ato realizado com palavras e se o proferimento foi feliz ou infeliz, esteja o verbo do ato de fala explícito ou não. No tocante a infelicidade do ato de fala, que se constitui em um ato malogrado, não apenas pela falta de sinceridade, mas por várias outras questões, Austin explica na doutrina das infelicidades que há uma especificidade.

Austin entende ser necessário seguir alguns passos para saber se o proferimento performativo é feliz, que ao proferir é sincero e segue todas as etapas que fazem parte da situação, que requer o engajamento de todos os sujeitos envolvidos. Para tanto, a situação deve ser convencionalmente aceita por todos os participantes de modo correto e completo. $\mathrm{O}$ ato ilocucionário é considerado feliz se corresponder aos sentimentos, pensamentos e intenções da pessoa que o invoca, que realiza uma ação com palavras. O desdobramento dessa ação resulta no esquema das condições de felicidade do proferimento performativo:

(A.1) Deve existir um procedimento convencionalmente aceito, que apresente um determinado efeito convencional e que inclua o proferimento de certas palavras, por certas pessoas, e em certas circunstâncias; e, além disso, que (A.2) as pessoas e circunstâncias particulares, em cada caso, devem ser adequadas ao procedimento específico invocado.

(B.1) O procedimento tem de ser executado, por todos os participantes, de modo correto e

(B.2) completo.

(Г.1) Nos casos em que, como ocorre com frequência, o procedimento visa às pessoas com seus pensamentos e sentimentos, ou visa à instauração de uma conduta correspondente por parte de alguns dos participantes, então aquele que participa do procedimento, e o invoca deve de fato ter tais pensamentos ou sentimentos, e os participantes devem ter a intenção de se conduzirem de maneira adequada, e, além disso,

(Г.2) devem realmente conduzir-se dessa maneira subsequentemente (AUSTIN, [1962] 1990, p. 30-31).

Ao elaborar o esquema que compõe todo o processo do dizer enquanto ato, Austin entende que acontecer alguns entraves no dizer é algo inerente aos atos de fala. Há uma iminência constante de quebras de alguma parte do dizer. Para acontecer embaraços basta que seja quebrada pelo menos uma dessas etapas. O filósofo afirma que a ocorrência da fala é algo tão próprio do ser humano que acontece naturalmente e espontaneamente.

Diante do exposto, Austin elaborou o esquema das condições do performativo com pontos que apontam para as etapas de proferimentos felizes no dizer. Contudo, qualquer quebra da sequência do dito ao se usar a linguagem para realizar coisas no mundo provoca, para o sujeito falante atropelos. 
Fazer coisas ao falar é algo que se faz com espontaneidade e sem preocupação de seguir tal esquematização. Sendo assim, tais etapas servem de esclarecimento para as análises dos atos de fala, isso porque a fim de identificação e descrição do dizer que não se cumpriu, tal qual planejado por aquele que proferiu tais e tais palavras.

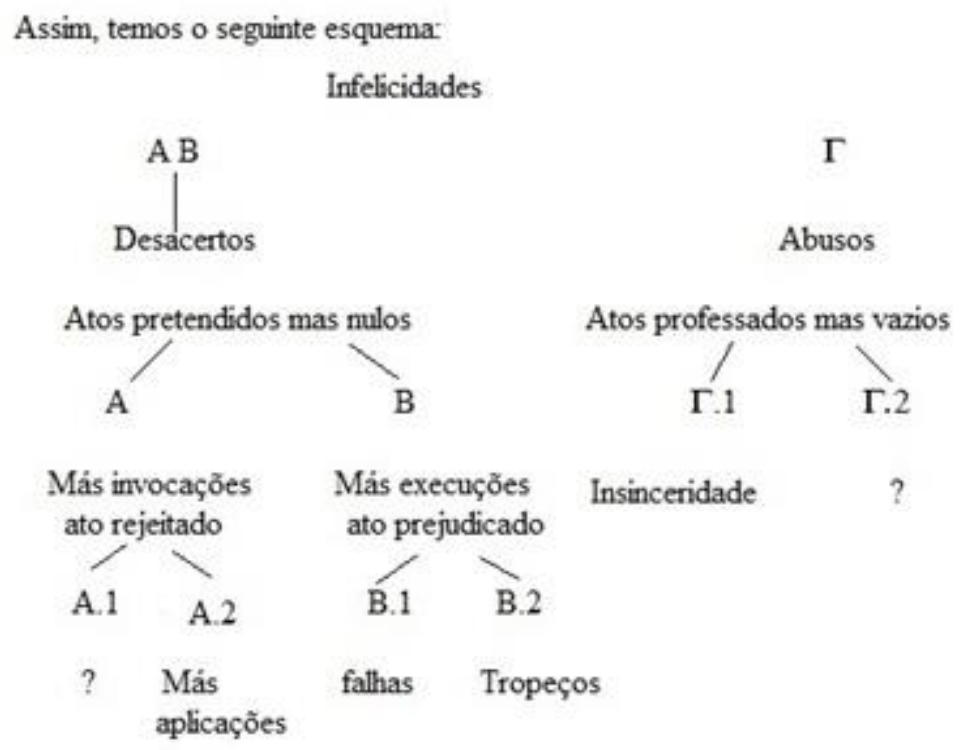

Fonte: Austin ([1962] 1990, p. 33)

Em resumo, o esquema das infelicidades é dividido em Desacertos e Abusos:

Os desacertos são atos pretendidos, mas nulos, que se dividem em (A e B).

Havendo más invocações (A), os atos são pretendidos pelo falante, contudo mesmo sendo realizado tornam-se nulos, são do tipo ato rejeitado, que estão subdivididos em A.1 - ? (Não há definição) e A.2 - Más aplicações.

No caso das más execuções (B) o ato é prejudicado e são do tipo B1 - Falhas e B2 Tropeços.

Os atos de fala do tipo abusos dividem-se em atos professados, mas vazios: Г.1 Insinceridade e no caso de Г.2 - ? (Não há definição).

Sobre as interrogações, Austin ([1962] 1990, p. 33) afirma: "Não me surpreende que haja dúvidas acerca de A.1 e Г.2, mas vamos adiar sua consideração”. Portanto, as análises realizadas até o momento pautam-se das categorias definidas pelo filósofo.

Não obstante, percebe-se que Austin assume uma postura flexível perante as possíveis interpretações dos casos de infelicidades no dizer coisas enquanto falas realizadoras de ações. $\mathrm{O}$ ato ao dizer ou por dizer palavras pode culminar em compromissos, perguntas e promessas, 
entre outras coisas. Além disso, o fazer pode afetar quem ouve ao ponto de causar reações, algumas vezes planejadas pelo falante, outras não. Austin ([1962] 1990, p. 89) assegura que “a realização de um ato nesse novo sentido, como sendo a realização de um ato 'ilocucionário', isto é, a realização de um ato ao dizer algo, em oposição à realização de um ato de dizer algo" [grifos do filósofo].

Como os atos ilocucionários são aqueles realizados quando o falante ao dizer algo, ou mesmo por dizer umas poucas palavras em contexto bem definido, realiza alguma ação, então a realização do ato de fala pode ser feliz e sem tropeços, desde que sejam cumpridas todas as etapas descritas anteriormente, ou infeliz e malograda, quando ocorre alguma quebra das regras descritas no esquema austiniano.

No caso de um casamento nos moldo cristãos, levando-se em conta todos os requisitos exigidos pela doutrina Católica. Inicia-se com os preparativos contam com a parte burocrática, que é a exigência de que seja dada entrada no processo nupcial na igreja, neste momento informam-se as testemunhas, marcada a data e entregue o batistério, original, assim como todos os documentos pessoais do noivo e da noiva. A cerimônia obedece ao ritual de realização com presença de celebrante institucionalmente investido, testemunhas e proferimento de palavras. O evento efetiva-se quando, no momento da celebração, é dado o “Sim, aceito", pelos noivos. A partir disso, eles passam para o rol dos casados.

Essa ocasião requer um contexto definido e institucionalizado. Não obstante, a quebra de qualquer etapa, principalmente, o proferimento do "Sim" acarreta na nulidade do casamento. Desse modo, é necessário analisar, a partir da teoria dos atos de fala, se o proferimento empreendido pelo falante atende o que propõe a sistematização do dizer como fazer e é um dizer que realiza atos, efetivamente.

No esquema proposto por Austin é possível estudar as situações em que o dizer não realiza atos devido aos tropeços ou falhas que provocam o malogro do dizer como fazer, ao longo da argumentação austiniana percebe-se que a separação em três tipos de atos de fala (locucionário, ilocucionário e perlocucionários) é um meio que o filósofo encontrou para esclarecer os atos de fala.

Na realidade, o dizer como fazer não pode ser segmentado tal como está apresentado nos esquemas. Contudo, tal organização do dizer, nos permite "distinguir o ato locucionário ‘ele disse que...' do ato ilocucionário ‘ele argumentou que...' e do ato perlocucionário 'ele me convenceu que..."” (AUSTIN, [1962] 1990, p. 90). 
Ao passo que se diz um proferimento performativo, a pessoa faz uso da linguagem e realiza ações. A cada proferimento sobressaem forças performativas, assim cada ato de fala tem uma força predominante que culmina em um tipo de ato de fala.

Por dizer um ato locucionário, se se descreve ou relata algo ou se faz a emissão de um proferimento. Em consonância com isso, caso o dizer implique em comprometimento do falante, então ocorre um ato ilocucionário, uma ação com palavras por parte daquele que o profere. Em seguida, se o dito provoca consequências e afeta o interlocutor, então é uma realização de um ato perlocucionário.

Basicamente, é possível ler uma sentença em latim, como exemplifica Austin, sem saber o sentido das palavras, o mesmo ocorre se se proferir frases em inglês, francês, alemão e outras línguas que não sejam conhecidas pelo sujeito. Embora a pessoa consiga proferir a frase corretamente, este é o típico dizer locucionário. São atos locucionários frases que descrevem uma determinada realidade, dita dentro de um contexto que não ganham força ilocucionária.

Frases do tipo: "Hoje é um dia ensolarado", "Today is sunny" ou "Está calor aqui", "It's hot here", se constituem frases locucionárias se ditas fora de contextos definidos. Isso porque, dizer "Está fazendo calor", em uma sala de aula onde os envolvidos possam inferir que é melhor abrir portas, pode ser um ato de fala ilocucionário, cuja força incide no(s) interlocutor(es), sendo predominantemente, um ato de fala perlocucionário.

Por meio dos atos de fala, em cada contexto específico, aquele que profere se compromete, por exemplo, ao dizer "prometo que estarei lá". No caso do ato de prometer, sendo este um ato bem sucedido, o resultado é a realização de uma promessa, seja na situação mais informal, um amigo diga para o outro "Pode contar comigo, eu vou!", ou mesmo com toda a formalidade, quando o empregado diz ao chefe, "Entregarei o relatório na data solicitada". Em ambas as situações realizar a ação de prometer algo a alguém implica em cumprir algumas etapas, como prometer com sinceridade e agir adequadamente para a realização do que foi prometido. Se se procede dessa maneira, então o ato ilocucionário é realizado com sucesso, porque quando se promete deve-se ter a intenção de cumprir com a palavra dada.

Não obstante, se o falante é insincero, então o ato é professado, mas vazio, isso se caracteriza como um abuso, do tipo (Г.1). Há um grau de complexidade quando se observa mais de perto a variável do ato de prometer, a qual consiste intrinsecamente na força daquele 
que faz a promessa e tem a intenção de fazer o prometido. Caso contrário, o dizer é infeliz e causa vários atropelos para as pessoas engajadas na situação de linguagem específica.

\section{FALAR É FAZER COISAS COM PALAVRAS}

$\mathrm{Na}$ conclusão de curso e na solenidade de formatura de todo curso de graduação é proferido pelos concluintes um juramento. Um estudante, representando toda turma, pede aos demais formandos que acompanhem o juramento, caso o curso seja Direito eles proferem juntos a seguinte promessa: "Prometo defender a liberdade, pois sem ela não há Direito que sobreviva, justiça que se fortaleça e nem paz que se concretize". Como se vê, é um proferimento performativo, na primeira pessoa do singular do presente do indicativo ativo. É um ato de fala genuinamente ilocucionário. Assim, o juramento é uma promessa, um ato de fala compromissivo, que deve ser vivido durante toda a vida profissional daquele que o fez.

Há atos de fala que incidem mais no ouvinte que no falante, no caso do pedido é justamente isso que acontece. Dizer é realizar atos que produzem determinadas reações sobre o(s) interlocutor(es) é realizar atos de fala perlocucionários. Embora Austin não tenha aprofundado os estudos sobre este tipo de ato de fala, é certo que "Temos, portanto, que separar bem a ação que fazemos (no caso, uma ilocução) de sua consequência (perlocução)" [Grifo nosso] (AUSTIN, [1962] 1990. P. 97).

Como no dizer pode-se ter um fazer, então é inerente a todo fazer a possibilidade de infelicidades. Escuta-se, principalmente na mídia, jornalistas dizerem que alguém foi infeliz ao dizer tal e tal coisa. Por exemplo, na crise aérea no Brasil, em 2007, a sexóloga Marta Suplicy, então ministra do turismo, fez a seguinte sugestão aos passageiros dos aeroportos brasileiros: "Relaxe e goze para esquecer-se dos transtornos". Essa ação da ministra foi infeliz, causando um grande embaraço, sobretudo nas pessoas atingidas pelo caos aéreo. À época, muitas delas dormiram nos aeroportos à espera da resolução do problema, todos queriam voltar para seus lugares de origem.

Em se tratando de atos de fala ilocucionários, este é o proferimento essencial para definir a força de uma ação com palavras, ao se dizer algo se realiza atos se, e somente se, forem satisfeitas as intenções da pessoa que profere a sentença performativa.

Primordialmente, o ato de se comprometer é feito usando a linguagem, então, o ato de fala ilocucionário é o tipo de proferimento que realiza atos, estabelece confiança entre sujeito falante e seu interlocutor e, por conseguinte, compromete o sujeito que o proferiu, sendo uma 
ação efetiva se o dito pelo falante for concretizado. Caso não haja a intenção de cumprir com o que prometeu e nada venha a acontecer, então este abuso do dizer como fazer torna o ato de fala infeliz, provocando atropelos e malogros.

No caso do proferimento perlocucionário, os efeitos provocados podem ser premeditados ou, na maioria das vezes, são inesperados, por isso mesmo que surpreende tanto quem falou como o seu interlocutor. Ainda mais, o dizer que provoca reação no interlocutor pode ser algo agradável ou desagradável, a depender das condições de realização. Ademais, atos perlocucionários não requerem de modo rigoroso a convenção, o institucional. Neste, sobressai a reação demonstrada por quem escuta aquele dizer que causa o inesperado.

Embora Austin não tenha tido tempo de aprofundar o tipo de ato de fala perlocucionário, e demonstrar mais detalhes dos efeitos, qual o conceito e outras peculiaridades, ele demonstrou adequadamente que o ato de fala perlocucionário provoca alguma reação do ouvinte. É certo que esta definição provoca discussões entre alguns filósofos. De fato, este é um ponto que tem sido bastante explorado na literatura.

Basicamente, essa distinção entre atos de fala locucionário, ilocucionário e perlocucionário é feita por Austin em caráter conceitual. Cada tipo de ato de fala e cada classe de força ilocucionária é apresentada com objetivo é explicar os três tipos de atos de fala (locucionário, ilocucionário e perlocucionário), cujas ocorrências foram divididas em cinco classes de forças ilocucionárias: Vereditivos, Exercitivos, Compromissivos, Comportamentais e Expositivos.

Para elaborar essa classificação, Austin partiu de uma metodologia específica, que visa o procedimento de usar a linguagem e a análise do verbo performativo. Este é o conceito que torna o dizer uma realização de atos, uma vez que as classes de força ilocucionária se interpenetram.

Os Vereditivos se caracterizam pela peculiaridade de falar ou escrever uma decisão. Nesse caso, se usa entre outros verbos: "Absolvo, condeno, constato (uma realidade)" (AUSTIN, [1962] 1990, p. 124).

Exercitivos são atos de fala que consistem no exercício de direitos e deveres com o uso da linguagem, por exemplo, o magistrado diz: "Julgo extinto este processo" quando legalmente instituído e imbuído do exercício de suas funções. Austin ([1962] 1990, p. 126) explica: "é uma classe muito ampla; alguns exemplos são: sentencio, declaro encerrado, declaro aberto". 
Compromissivos são atos de fala de comprometimento por parte do falante. O sujeito que assume uma determinada linha de ação. Por exemplo, em uma negociação uma pessoa usa a sua assinatura no contrato ou simplesmente emite a sua promessa em cumprir a palavra dada, alguns verbos são: "Prometo, me comprometo a, dou a minha palavra" (AUSTIN, [1962] 1990, p. 127).

Os atos de fala comportamentais apresentam ideia de conduta daquele que fala em relação aos que participam da situação específica de uso de linguagem. Por exemplo, a retratação de alguém, cuja integridade tenha sido agredida com palavras desapropriadas só pode ser feita se algumas palavras forem ditas no momento certo e no lugar adequado. Geralmente, o ato de pedir desculpas só pode ser realizado se se disser algumas palavras: "Para pedir desculpas temos 'peço desculpas' e para agradecer 'agradeço"” (AUSTIN, [1962] 1990, p. 129).

A classe dos Expositivos contém verbos que consistem em expressar opiniões, afirmações, argumentos e muitos outros atos de fala referentes ao ato de expor algo a alguém. Por exemplo, o promotor de justiça expõe sua argumentação, porque ele faz a reconstrução da cena de um crime baseado nos autos e em investigações realizadas previamente. Alguns verbos dessa classe, segundo Austin ([1962] 1990, p. 131) são: “Afirmo, nego, declaro, descrevo, classifico e identifico".

$\mathrm{Na}$ dinâmica de acontecimentos com o uso do dizer como fazer, o fazer coisas com palavras entrelaça as classes, por exemplo, na classe dos Vereditivos está o ato judicial que pode ser um exercitivo, "alguns atos judiciais, no sentido de atos feitos por um juiz em vez de serem feitos por um corpo de jurados, por exemplo, são realmente exercitivos" (AUSTIN, [1962] 1990, p. 124-125). Isso ocorre porque dar um veredicto, no contexto do magistrado, é o momento em que este exerce a sua função.

Descrever é a realização do ato de fala declarativo, uma descrição do tipo: "Meu celular desapareceu", em uma sala de aula pode ser vista por uns como um ato de fala que constata um acontecimento. Contudo, outro aluno pode reagir dizendo: "Colegas, vamos procurar o celular da professora!". Este, entendeu o ato de fala como um pedido de ajuda. Outras reações são possíveis, obviamente. Veja, em outro contexto, dizer a mesma frase provoca reações cujas dimensões são incalculáveis. O dito "Meu celular desapareceu" a um delegado é uma denúncia. Esta frase, nesse contexto, serve para que seja registrado o Boletim de Ocorrência (BO), este documento comprova que o celular não está mais sob o poder do sujeito. Em ambos os casos foram realizados atos de fala. 
Digamos que após o proferimento do ato de fala acima, depois de ter prestado queixa na delegacia, o celular aparece. Nesse caso, houve um tropeço no ato de fala, que foi malogrado e pode ter sido fonte de algumas infelicidades do dizer. Alguns interlocutores podem ter se sentido muito mal e estado de suspeição pelo telefone da professora ter desaparecido na sala de aula e o documento registrado na delegacia torna-se sem efeito, sendo necessário que seja informado o aparecimento do objeto. Estes são alguns embaraços, tropeços e mal-entendidos. Assim, o ato de fala performativo, embora não admita a verificação da veracidade ou falsidade do dito, pode ser analisado a partir do conceito de ato de fala feliz ou infeliz.

Austin pergunta qual é o alcance da infelicidade do dizer a fim de fundamentar a concepção de que "parece evidente que a infelicidade é um mal herdado por todos os atos cujo caráter geral é ser ritual ou cerimonial, ou seja, por todos os atos convencionais" [Grifos do autor] (AUSTIN, [1962] 1990, p. 34).

Com isso, Austin quer dizer que "as ações em gerais, não todas, são passíveis, por exemplo, de serem executadas com dificuldades, ou por acidente, ou devido a este ou àquele tipo de engano, ou mesmo, sem intenção" (AUSTIN, [1962] 1990, p. 35).

$\mathrm{O}$ ato de fala é algo dito de modo consciente, ainda assim, os efeitos desse dizer não são previsíveis. Tanto que é difícil realizar o ato de fala ilocucionário com o fim de convencer de que não era aquilo que se queria fazer/dizer. As consequências sobre os sentimentos e pensamentos do ouvinte ou de outras pessoas engajadas na referida situação não deixam de ser surpreendentes.

Um exemplo de ato de fala feliz, entre tantos outros, em contexto bem definido, a menina Laura ganhou um cachorro de presente, na ocasião o seu pai lhe perguntou: qual é o nome que você vai dar ao seu cão? Imediatamente, ela respondeu: “Jack! Vamos chamá-lo Jack". Nesse momento, o ato de fala ilocucionário de "batizar" o cão é proferido pela menina e todos da casa passam a tratar o novo morador com esse nome. Contudo, no contexto institucional do cristianismo, o padre que é a pessoa ordenada para batizar pessoas, estava em plena solenidade deum batizado quando errou o nome da criança, provocou uma reação imediata nos participantes que trataram de informar o nome correto, esse simples lapso causou um embaraço momentâneo, foi comentário no almoço de comemoração daquela família e marcou a história de vida daquela criança.

Nesse sentido, há possíveis acertos e desacertos dos atos de fala, o que provoca, por vezes, efeitos inesperados no(s) interlocutor(es). Ao classificar a força do dizer quanto à 
performatividade, Austin propõe observar especificamente os proferimentos performativos, mesmo que provisório, que são as classes supracitadas. Na verdade, o filósofo admite não ter definido plenamente e satisfatoriamente cada classe ao afirmar que os vereditivos, exercitivos, Compromissivos, Comportamentais e Expositivos

Essa classificação geral dos verbos é feita a partir do performativo explícito, lembrando que isso ocorre quando a forma verbal da primeira pessoa do singular do presente do indicativo ativo. O reforço dessa informação é primordial quando a preocupação, aqui, é explicitar as infelicidades do dizer. Isso porque ao magistrado, em exercício de suas funções, cabe emitir juízos que funcionam como vereditos legais, os quais decidem se um réu, por exemplo, volta para casa e vai retomar a convivência social ou sai daquela audiência diretamente para a cadeias.

No que concerne à vocação e natureza da linguagem, a classificação austiniana contribui claramente ao propor, de modo inequívoco, um redirecionamento dos estudos cujo objeto é o ato de falar, colocando em realce alguns dizeres que nada descrevem nem relata, são ações efetivas na vida social de todas as pessoas.

Por um lado, Austin sistematiza as categorias que fundam a teoria dos atos de fala, assim, redimensiona o olhar da filosofia para os estudos acerca da linguagem. A característica austiniana é, de fato, não fechar as discussões como sendo dele a última palavra sobre o assunto, isso fica claro na XII Conferência, quando afirma que todo seu trabalho de classificação deve ser visto como uma proposta. Esta, rompe com as bases dos estudos da tradição linguístico-filosófica, isso porque antes de Austin alguns estudos apontam teorias sobre linguagens simbólicas, matemáticas, entre outras. Este tipo de análise da linguagem se pauta em exemplos artificiais, ou seja, não partem da linguagem em uso. No caso da proposta austiniana, o contexto é um elemento essencial para se entender, analisar e explicar o dizer como fazer, somando-se a isso as pessoas engajadas com seus pensamentos, crenças e intenções, as instituições que enformam o dizer. Estes pontos dão o caráter realizador do ato de fala feliz ou infeliz.

O sujeito usa palavras e/ou frases para relatar coisas, mas não somente para isso, com elas realizam-se atos de fala. É essencial entender o que faz o ato de fala ser feliz ou infeliz, sobretudo o que se passa quando ocorre ação com palavras. Pelo que foi exposto até o momento, vê-se que são inúmeras as razões que provocam na ação com palavras a possibilidade de ser malsucedida. 
Decorre disso, a relevância de se abordar a doutrina das infelicidades segundo Austin, uma série de fatores que podem contribuir para que algo não se realize como o esperado na execução de um ato de fala, tornando o dizer de alguém infeliz.

\section{CONSIDERANDO ALGUNS PONTOS DA TEORIA DOS ATOS DE FALA}

Os proferimentos performativos, que estão para além do linguístico, equivalem ao ato de fala que responde ao critério de ser feliz ou infeliz. Ao analisar frases que são atos efetivos na realidade, Austin chegou à conclusão que o critério gramatical (ou lexicográfico) não era tão claro quanto lhe pareceu no início, não encontrando na gramática uma saída para esse tipo de problema, embora algumas vezes parta da análise do proferimento a partir do performativo explícito.

Ainda assim, no primeiro momento tanto performativo como constatativo apresentam características peculiares, o que levou o filósofo a propor a distinção entre estes tipos de atos de fala. Tal distinção permitiu ao filósofo perceber pontos referentes ao campo da Ética, embora posteriormente ele tenha se certificado que não procede fazer a separação do ato de declara coisas acerca do mundo e de fazer coisas palavras, uma vez que o contexto, as pessoas, a instituição e as convenções, entre outras variáveis, são fundamentais para que um proferimento ganhe a força predominante do dizer, que pode ser relato, pedido, ordem, legado, ou promessa, entre outros fazeres.

É pelo critério de performatividade que se sabe a natureza do proferimento que se caracteriza como uma promessa ou uma elaboração de regras, por exemplo. Na prática pode ocorrer situação, a mais diversa, passível da análise com base na Doutrina das Infelicidades austiniana. Atos de fala podem realmente ser bem ou malsucedidos.

Por exemplo, uma fictícia associação, que realiza um planejamento da Assembleia de intelectuais consagrados da liga especial de Héstia, a comissão organizadora designa Heleia para fazer a abertura do evento. Isso porque esta intelectual atende a alguns dos requisitos exigidos pela cúpula.

No entanto, no dia marcado, Heleia ficou muito doente, pensando que ficaria melhor na hora até o evento não comunicou aos organizadores. Ela sabia da importância do evento, de seu comparecimento e, por isso, havia preparado um discurso bastante apropriado para a situação, inclusive, foi dada a ela a honra de proferir as palavras seguintes palavras "Considero aberta esta assembleia". 
No entanto, a noite chegou e com ela a hora da abertura do evento. Heleia estava pior visivelmente convalescente, mesmo assim foi até o auditório, que estava lotado de interlocutores ávidos por escutar a palestrante, conforme previsto. Impossibilitada até de falar com clareza devido ao seu estado de saúde ter se agravado, Heleia escuta a mestre de cerimônia ler o seu extenso currículo e, por fim, convidá-la à mesa da conferência. Silenciosa, devagar e com dificuldade levantou-se e foi andando devagar. Ao chegar na mesa tratou logo de se sentar, com um olhar profundo e abatido disse para a pessoa que tinha anunciado o seu nome, em voz baixa, quase sussurrando, "Não consigo dizer nada, estou muito mal, por favor, faça a abertura por mim". A moça do cerimonial, vendo o estado da famosa Heleia disse imediatamente: "Declaro aberta a Assembleia".

Tomou a famosa conferencista pelo braço e a encaminhou ao hospital mais próximo. $\mathrm{O}$ auditório, que nada entendia naquela situação entrou em pânico. A pergunta que fica é a seguinte: por que o ato de abrir o evento não foi feito pela pessoa institucionalmente aceita para tal, o evento foi considerado aberto?

O que houve foi um ato de fala malogrado, que se deu pelo fato das condições de felicidade não terem sido satisfeitas, isto é, o critério (A.2) não foi atendido (as pessoas e circunstâncias particulares, em cada caso, devem ser adequadas ao procedimento específico invocado). O proferimento não foi feito pela pessoa institucionalmente e convencionalmente designada para invocar o ato de fala de declarar aberta a assembleia. $O$ fato de outra pessoa ter proferido o ato de fala, torna este ato de fala infeliz, porque não ocorreu de modo correto e completo (Violação dos critérios B1 e B2). Portanto, é requisito para performativos felizes saber o objetivo, primordial, do proferimento, quem deve invocá-lo e em quais condições isso deve ser feito.

Um dizer, seja para constatar algo em uma situação ou para realizar atos (pedir, ordenar algo a alguém, ou mesmo outros performativos), obedece à critérios de felicidade e quando há quebras, há falhas e tropeços, mudando o rumo da realidade onde o ato de fala foi feito. Foi isso que aconteceu na abertura da referida assembleia.

Nesse artigo analisamos as condições para performativos felizes por meio do esquema de infelicidades austiniano. Ficaram algumas questões, a saber, que tipo de ação torna o ato de fala desacerto e abuso ao mesmo tempo? Quais as possibilidades de propor elementos para as duas interrogações deixadas por Austin no referido esquema?

Com efeito, ao se dizer "Está quente, aqui” pode-se fazer a constatação fatídica de que a temperatura do tempo está alta. Este mesmo proferimento, em outra situação, pode ser um 
pedido para alguém abrir a janela ou ligar o ar condicionado, coisas do tipo. E, por último, sem fechar esta discussão, se no meio de um diálogo alguém diz que a discussão "está quente", tal proferimento é uma declaração. Mas, se todos estão em uma sala refrigerada, estando o ar condicionado em $18^{\circ}$ e alguém diz “está quente, aqui”, muito provavelmente este ato de fala será infeliz, porque possivelmente haverá alguém que contra argumentará. Assim, são muitas as condições que contribuem para o dizer como fazer. São esses detalhes que fazem palavras virarem uma ação tão efetiva quando o ato de dar um passo.

\section{REFERÊNCIAS}

AUSTIN, J. L. How to do things with words. Oxford: Oxford Univ. Press, 1962.

AUSTIN, J. L. Quando dizer é fazer: palavras e ações. Trad. de Danilo Marcondes de Sousa Filho. Porto Alegre: Artes Médicas, 1990.

COSTA, C. F. Revendo a distinção constatativo/performativo. Revista Princípios: Natal; 1995.

COULTHARD, Malcolm. Na introduction to discourse analysis. Harlow: Essex, Longman, 1985 .

MARCONDES, D. Filosofia, linguagem e comunicação. São Paulo: Cortez, 1992.

MARCONDES, D. Desfazendo mitos sobre a pragmática. ALCEU Revista de Comunicação Cultural e Política, Rio de Janeiro, v. 1, n., p. 38-46, 2000.

MARCONDES, D. Desenvolvimentos recentes na teoria dos atos de fala. In: Que faz pensar $\mathrm{n}^{\circ} 17$, dezembro de 2003.

MARCONDES, D. A pragmática na filosofia contemporânea. Rio de Janeiro: Jorge Zahar, 2005a.

MARCONDES, D. Revendo a distinção tradicional: sintaxe, semântica, pragmática. In: João A. Mac Dowell; Marcelo Y. Yamamoto. (Org.). Linguagem e linguagens. São Paulo: Loyola, 2005b, p. 95-128.

OTTONI, Paulo R. Visão performativa da linguagem. São Paulo: UNICAMP, 1998.

PENCO, C. Introdução à filosofia da linguagem. Petrópolis: Vozes, 2006.

PONZIO, Augusto; CALEFATO, Patrizia; PETRILLI, Susan. Fundamentos de filosofia da linguagem. Petrópolis: Vozes, 2007. 
RAJAGOPALAN, Kanavillil. O Austin do qual a Lingüística não tomou conhecimento e a Lingüística com a qual Austin sonhou. Cadernos de estudos linguísticos. Campinas, n. 30, p. 105-116, jan/jun. 1996.

RAJAGOPALAN, Kanavillil. On Searle [on Austin] on language. Language and Communication, Grã-Bretanha, v. 20, n. 4, p. 347-391, 2000.

ROSS, A. Grandeza y Decadencia de la Doctrina de las Expressiones Realiativas. In: El Concepto de Validez y Otros Ensayos. México: Fontamara, 1997.

ROSS, A. Nova pragmática: fases e feições de um fazer. São Paulo: Parábola, 2010.

SEARLE, John. R. Speech acts: an essay in the philosophy of language. Cambridge: Cambridge University Press, 1969.

SEARLE, John. Os atos de fala: um ensaio de filosofia da linguagem. Coimbra: Almedina, 1981.

SEARLE, John. Expression and meaning. 1979. Uma taxinomia dos Atos Ilocucionários. In: Expressão e Significado: estudos da Teoria dos atos de fala. São Paulo: Martins Fontes, 1995.

SLAIBI FILHO, Nagib. Sentença cível: fundamentos e técnica. Rio de Janeiro: Forense, 2001.

SUPREMO TRIBUNAL FEDERAL-STF. DISPONÍVEL EM:

http://www.stf.jus.br/arquivo/djEletronico/DJE_20130419_074.pdf ACESSO EM: 04 MAI 2013.

WITTGENSTEIN, L. Investigações filosóficas. São Paulo: Nova Cultural, 2005. 